\title{
Elimination of arsenic traces contained in liquid effluents by chromatographic treatment
}

\author{
T. Guenegou ${ }^{1, *}$, A. Tambute ${ }^{2}$, A. Jardy ${ }^{1}$ and M. Caude ${ }^{1}$ \\ ${ }^{1}$ Laboratoire Environnement et Chimie Analytique, École Supérieure de Physique et Chimie Industrielles \\ de Paris (associé au CNRS), 10 rue Vauquelin, 75231 Paris Cedex 05, France \\ ${ }^{2}$ Direction des Centres d'Expertise et d'Essais, Établissement Technique Central $N^{\circ} 4$, \\ Centre d'Études du Bouchet, BP. 3, Le Bouchet, 91710 Vert-Le-Petit, France
}

\begin{abstract}
Our present work is included in a development plan of a two-step detoxication process of arsenical by-products originated from chemical warfare destruction effluents [1]. The first method studied was classical anion exchange chromatography. Less than $1 \%$ of the anion exchanger capacity is used to fix arsenate ions for a $\mathrm{Cl}^{-} / \mathrm{AsO}_{4}^{3-}$ concentration ratio equal to 100 . Because of the lack of anion exchanger selectivity, the use of more selective adsorbents has been investigated, namely a macroporous cation exchange resin (BioRad AGMP-50 resin). We confirm that the $\mathrm{As}^{\mathrm{III}}$ and $\mathrm{As}^{\mathrm{v}}$ retention does not depend on the nature of the resin functional groups and that only the ferric hydroxide precipitate is involved in the retention. We also show that the arsenic available exchanger capacity is not significantly affected by high concentrations in chloride ions $\left(1 \mathrm{~mol} \mathrm{~L}^{-1}\right)$, and it seems that the kinetics of arsenite and arsenate ions fixation is better in presence of chlorides. The use of the exchanger for the complete detoxication of arsenic trace (10 ppm) solutions in presence of high contents in chlorides $\left(1\right.$ to $\left.3 \mathrm{~mol} \mathrm{~L}^{-1}\right)$ leads to an effluent volume equal to 280 and 540 times the resin bed volume, for $\mathrm{As}^{\mathrm{III}}$ and $\mathrm{As}^{\mathrm{V}}$ respectively. The effluent thereby obtained has an arsenic concentration lower than the M.C.L. (100 ppb).
\end{abstract}

Key words. Arsenic oxoanions elimination - ferric hydroxide - chromatography - environmental safety standards.

\section{Introduction}

The hydrolysis solution detoxication of chemical warfare called Lewisite $[1]\left(\left[\mathrm{AsO}_{2}^{-}\right] \approx 0.1 \mathrm{~mol} \mathrm{~L} \mathrm{~L}^{-1},\left[\mathrm{Cl}^{-}\right] \approx\right.$ $1 \mathrm{~mol} \mathrm{~L}-1,\left[\mathrm{OH}^{-}\right] \approx 1 \mathrm{~mol} \mathrm{~L}{ }^{-1}$ ) requires a chemical treatment in two steps.

The objective of the first one is to eliminate the major part of arsenic under an insoluble form with a high arsenic content. We have shown in a previous paper [1] that this can be reached by trapping the arsenite and arsenate ions during the ferric hydroxide precipitation. In the optimal operating conditions $(1<$ initial molar ratio $\mathrm{Fe} / \mathrm{As}<1.5)$, a high arsenic confining $(2 / 3<$ molar ratio $\mathrm{As} / \mathrm{Fe}$ in the precipitate $<1$ ) and an elimination rate higher than $99 \%$ are obtained. However, the residual arsenic content in the liquid effluents is about $10 \mathrm{ppm}$ that is two order of magnitude greater than the arsenic's Maximum Contaminant Level (M.C.L.) tolerated in France (100 ppb [2]). So liquid effluents need a further detoxication, this step is the goal of this paper.

In order to achieve a high throughput, an effluent dynamic treatment on chromatographic columns may be convenient. Two ways can be considered:

- first the use of classical anion exchangers [3,4], but taking into account the high chloride content of the effluents we can expect the necessity to operate under conditions where arsenic oxoanions are highly charged.

- the second way is to operate with a very selective adsorbent [3-13]. Furthermore, in order to implement an industrial process, the final decontamination must involve sorbents that are commercially available and not too expensive.

\section{Experimental part}

\section{Reagents}

Nitric acid 1M, Titrinorm, sodium arsenite and di-sodium hydrogenoarsenate, Rectapur, hydrochloric acid min. 35\%, ammonium nitrate and sodium chloride, Normapur, Arsenic A.A.S. standard solution and sodium hydroxide $1 \mathrm{M}$, Normadose, iron(III) chloride anhydrous, are purchased from Prolabo (Paris, France), nickel(II) nitrate hexahydrate, from Merck (Darmstadt, Deutschland) and sodium hydroxide, $50 \%$ solution, from Baker (Deventer, Hollande).

\section{Apparatus \\ Graphite Furnace Atomic Absorption Spectrometer}

Arsenic present in the chromatographic effluent is determined by furnace atomic absorption spectrometry. We use the SpectrAA-300 model (Varian, Les Ulis, France) with electrothermal atomisation platform and Zeeman background correction.

An aqueous solution of nickel nitrate $\left(1 \mathrm{~g} \mathrm{~L}^{-1}\right)$ allows to stabilize arsenic at high temperatures. In the chloride matrix, an additional modifier (ammonium nitrate $1 \mathrm{~mol} \mathrm{~L}^{-1}$ diluted in nitric acid $0.15 \mathrm{~mol} \mathrm{~L}^{-1}$ ) is used to avoid the arsenic volatilization (arsenic gives volatile compounds with chlorides $\left(\mathrm{AsCl}_{3}, \mathrm{AsCl}_{5}\right)$ but chloride ammonium is much more volatile).

All analyses are carried out in nitric acid media $(\mathrm{pH} 2)$ in order to make easier the organic compounds destruction.

* Correspondence and reprints.

Received July 10, 1998; revised September 18, 1998; accepted September 25, 1998. 


\section{Original articles}

\section{Pump and fraction collector}

A 302-303 model pump associated with a 202 model fraction collector (Gilson, Villiers le Bel, France) has been used.

\section{Chromatographic columns and stationary phases}

\section{Anion exchanger}

A glass column equipped with an adjustable piston $(24.7 \times$ $1 \mathrm{~cm}$ i.d.) was packed, with AG1X-8 strong basic anion exchanger resin (ion exchange capacity $=1 \mathrm{meq} \mathrm{mL}^{-1}$, density $=0.7 \mathrm{~g} \mathrm{~mL}^{-1}, 200-400$ mesh, Bio-Rad laboratories) under chloride form, according to the slurry packing technique under atmospheric pressure.

\section{Cation exchanger}

A stainless steel column $(47 \times 1 \mathrm{~cm}$ i.d. or $13 \times 1 \mathrm{~cm}$ i.d. $)$ was packed with AGMP-50 macroporous strong acid cation exchanger resin (ion exchange capacity $=1.5 \mathrm{meq} \mathrm{mL}^{-1}$, density $=0.8 \mathrm{~g} \mathrm{~mL}^{-1}, 100-200$ mesh, Bio-Rad laboratories) under hydrolyzed $\mathrm{Fe}^{\mathrm{III}}$ form. This latter was obtained as follows:

The resin initially under $\mathrm{H}^{+}$form is converted under $\mathrm{Fe}^{3+}$ form by equilibration with a ferric chloride $\left(1 \mathrm{~mol} \mathrm{~L}^{-1}\right)$ solution in nitric acid $0.1 \mathrm{~mol} \mathrm{~L}^{-1}$ added in excess. We have checked that the resin conversion to $\mathrm{Fe}^{3+}$ is complete by percolating a fresh $\mathrm{Fe}^{3+}$ solution $\left(1 \mathrm{~mol} \mathrm{~L}^{-1}\right)$. After filtration and washing with water, the resin under $\mathrm{Fe}^{3+}$ form is mixed with a sodium hydroxide solution $1 \mathrm{~mol} \mathrm{~L}^{-1}$ (added in excess) in order to precipitate ferric hydroxide in the resin pores. In this way, ferric hydroxide is scattered within the porous volume of the resin. Finally the column is packed as previously.

\section{Experimental results}

\section{Elimination of arsenite and arsenate ions by pure ion exchange chromatography}

Figures $1 \mathrm{~A}$ and $1 \mathrm{~B}$ represent the repartition diagrams of the different soluble forms of $\mathrm{As}^{\mathrm{V}}$ and $\mathrm{As}^{\mathrm{III}}$ respectively [14] and the variations of their apparent charges versus the $\mathrm{pH}$. We

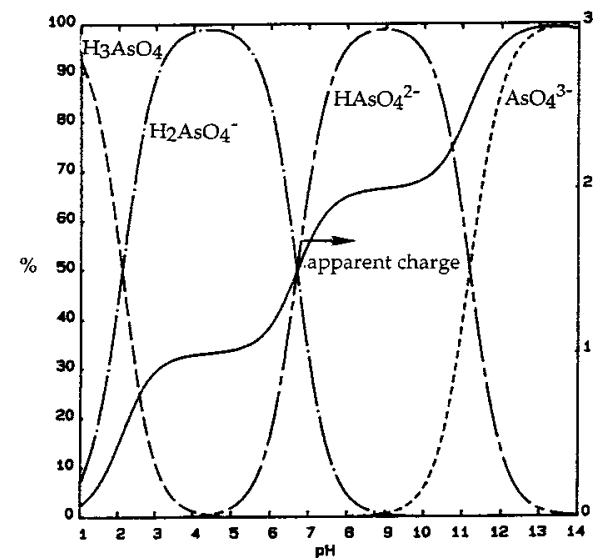

Fig. 1A. Distribution diagram of arsenate forms [14] and variation of the apparent charge (absolute value) versus the $\mathrm{pH}$.
Table I. Variation of the arsenate available capacity versus the chloride ion concentration.

\begin{tabular}{lccc}
\hline \multicolumn{1}{r}{$\begin{array}{c}\text { OPERATING } \\
\text { CONDITIONS }\end{array}$} & 1 & 2 & 3 \\
PARAMETERS & & & \\
\hline$\left[\mathrm{AsO}_{4}^{3-}\right] \mathrm{mol} \mathrm{L}^{-1}$ & $2 \times 10^{-2}$ & $2 \times 10^{-3}$ & $2 \times 10^{-2}$ \\
{$\left[\mathrm{Cl}^{-}\right] \mathrm{mol} \mathrm{L}^{-1}$} & $1.3 \times 10^{-1}$ & $1.3 \times 10^{-1}$ & 2 \\
{$\left[\mathrm{AsO}_{4}^{3-}\right] /\left[\mathrm{Cl}^{-}\right]$} & 0.154 & 0.015 & 0.01 \\
Exchanged arsenate capacity & & & \\
(mmol.) & $9.35 \times 10^{-1}$ & $1.9 \times 10^{-1}$ & $6 \times 10^{-2}$ \\
Capacity* (\%) & 9.5 & 2 & 0.6 \\
\hline
\end{tabular}

*: (exchanged $\mathrm{AsO}_{4}^{3-}$ quantity)/(exchange capacity of the resin, expressed in $\left.\mathrm{AsO}_{4}^{3-} \mathrm{mmol}\right) \times 100$.

Resin: AG1X-8 basic anion exchanger.

can see it is easier to obtain the tricharged anionic form with $\mathrm{As}^{\mathrm{V}}$ ( $\mathrm{pH}$ 12) than with $\mathrm{As}^{\mathrm{III}}$ (partially obtained at $\mathrm{pH} 14$ ). The greater the charge of an ion, the higher the affinity of an ion exchanger. Consequently, we have chosen to study the arsenate retention in presence of chloride ions at various concentration ratios.

The results are gathered in table I. As expected and although these two anions have a charge different, the exchanger selectivity towards arsenate is too low to counterbalance the high chloride anion concentrations. For a concentration ratio $\mathrm{Cl}^{-} / \mathrm{AsO}_{4}^{3-}$ equal to 100 the arsenate available capacity is only $0.6 \%$ of the whole anion exchanger capacity. So it is obvious this classical anion exchanger is not suitable for the arsenic trace elimination in the effluent.

\section{Elimination of arsenite and arsenate anions with a selective stationary phase}

\section{Choice of the stationary phase}

Several selective adsorbents exhibiting a selective retention towards arsenite and arsenate ions have been described; they are summarized in table II.

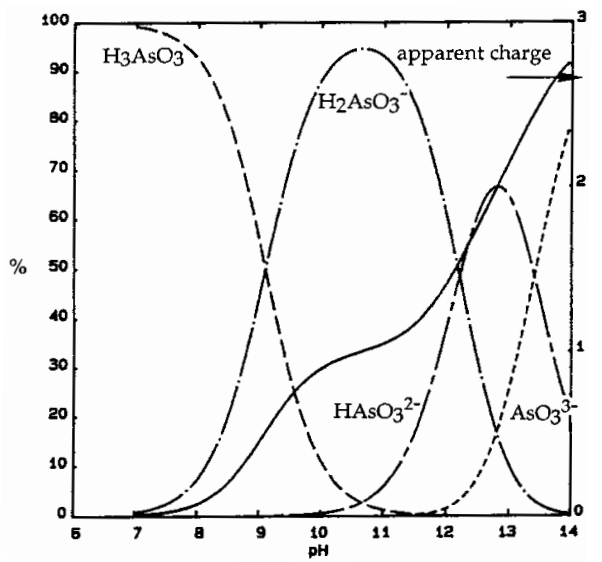

Fig. 1B. Distribution diagram of arsenite forms [14] and variation of the apparent charge (absolute value) versus the $\mathrm{pH}$ (case of an initial concentration of arsenite lower than the $\mathrm{H}_{3} \mathrm{AsO}_{3}(\mathrm{~s})$ solubility). 


\section{Original articles}

Table II. Selective adsorbents used for the arsenic retention.

\begin{tabular}{|c|c|c|c|c|}
\hline \multirow[t]{2}{*}{ Adsorbent } & \multirow{2}{*}{$\begin{array}{l}\text { capacity } \\
(m g \text { As } / g)\end{array}$} & \multicolumn{2}{|c|}{ As (ppm) } & \multirow[t]{2}{*}{ References } \\
\hline & & Influent & effluent & \\
\hline $\begin{array}{l}\text { Resin Dow XFS- } \\
4195 \text { used in its } \\
\text { hydrolysed Fe(III) } \\
\text { form }\end{array}$ & 50 & 150 & $<1$ & 7 \\
\hline $\begin{array}{l}\text { Resin Chelex } 100 \\
\text { used in its } \\
\text { hydrolysed Fe(III) } \\
\text { form }\end{array}$ & $45 * 70 * *$ & 150 & $<1$ & 6 \\
\hline $\begin{array}{l}\text { hydrous titanium } \\
\text { oxide }\end{array}$ & 1.24 & 5 & 0.03 & 5 \\
\hline $\begin{array}{l}\text { hydrous ferric oxide } \\
\text { binded with a } \\
\text { polyacrylamide }\end{array}$ & 23 & $10^{4}$ & 500 & 8 \\
\hline actived carbon & 1.8 & 144 & 135 & 4 \\
\hline actived alumina & 12.4 & 144 & 82 & 4 \\
\hline ferrous sulfide & 12.6 & 144 & 18.4 & 4 \\
\hline $\begin{array}{l}\text { silica gel } \\
\text { impregnated with } \\
\text { ferric hydroxide }\end{array}$ & 5.6 & 100 & - & 9 \\
\hline $\begin{array}{l}\text { titanium oxide } \\
\text { impregnated with } \\
\text { ferric hydroxide }\end{array}$ & 8.7 & 2.9 & - & 10 \\
\hline $\begin{array}{l}\text { titanium oxide } \\
\text { mixed with ferric } \\
\text { hydroxide }\end{array}$ & 3.2 & 2.5 & - & 10 \\
\hline $\begin{array}{l}\text { alumina } \\
\text { impregnated with } \\
\text { ferric hydroxide }\end{array}$ & 3.5 & 3.5 & - & 10 \\
\hline $\begin{array}{l}\text { mixture } 1: 1 \mathrm{Al}_{2} \mathrm{O}_{3} \\
\text { and } \mathrm{TiO}_{2} \text { each } \\
\text { other impregnated } \\
\text { with ferric } \\
\text { hydroxide }\end{array}$ & 4.2 & 4.0 & - & 10 \\
\hline
\end{tabular}

*: $45 \mathrm{mg} \mathrm{As} / \mathrm{g}$ of adsorbent.

**: $70 \mathrm{mg} \mathrm{As}$ III/g of adsorbent.

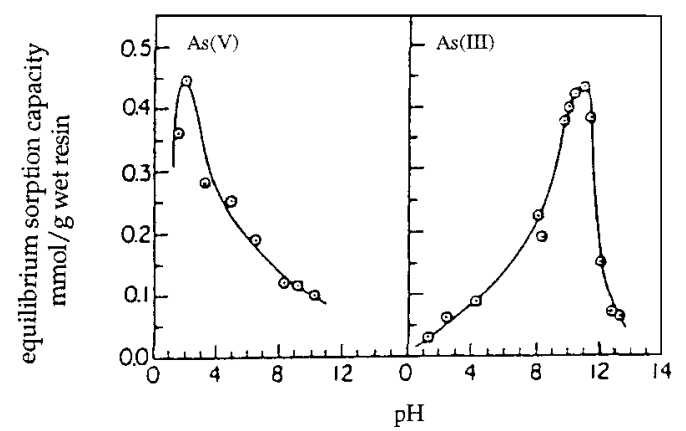

Fig. 2. Effect of the pH on equilibrium sorption of arsenate and arsenite with the Chelex $\left(\mathrm{Fe}^{\mathrm{III}}\right)$ resin (initial concentration of $\mathrm{As} s^{\mathrm{III}}$ and $\mathrm{As}^{\mathrm{V}} 4 \mathrm{mmol} \mathrm{L}^{-1}$; resin loading $4 \mathrm{~g}$ (wet) $\mathrm{L}^{-1}$; temperature $24{ }^{\circ} \mathrm{C}$ ) [6].
We can notice that almost all studied sorbents use ferric hydroxide as selective species. Moreover both resins Chelex 100 [6] (a cross-linked polystyrene matrix with iminodiacetic functional groups) and DOW XFS 4195 [7] (a crosslinked polystyrene matrix with bis(2-picolylamine) functional groups) give the highest arsenite and arsenate available capacity and selectivity.

From [6], the $\mathrm{Fe}^{\mathrm{III}}$ hydrolysis would lead to the substitution of hydration $\mathrm{H}_{2} \mathrm{O}$ molecules of the ferric cation by $\mathrm{OH}^{-}$ ions. The variations of arsenite and arsenate ion retentions versus the $\mathrm{pH}$ (Fig. 2 [6]) shows the $\mathrm{As}^{\mathrm{III}}$ and $\mathrm{As}^{\mathrm{V}}$ retention is maximal in the $\mathrm{pH}$ range where the $\mathrm{H}_{2} \mathrm{AsO}_{3}^{-}$and $\mathrm{H}_{2} \mathrm{AsO}_{4}^{-}$ species predominate (cf. Figs. 1A and 1B). Consequently, these authors suggest an ion exchange of a hydroxide $\left(\mathrm{OH}^{-}\right)$ with a monovalent anionic species as $\mathrm{H}_{2} \mathrm{AsO}_{3}^{-}$and $\mathrm{H}_{2} \mathrm{AsO}_{4}^{-}$ according to the reaction:
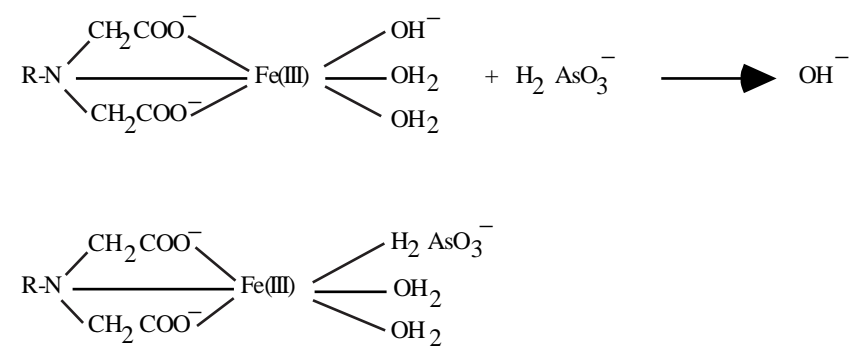

Unfortunately the fact that the arsenic capacity is not modified or even increased [6] in the presence of chloride ions at various concentration invalidates such an ion exchange mechanism.

Preliminary tests were carried out with the chelating resin Chelex 100 under the optimal operating conditions described in [6] for arsenite ions ( $\mathrm{pH}$ 10.5). Although the retention of arsenite ions is efficient (no arsenic detected by A.A.S. in the effluent after $50 \mathrm{~mL}$ for a percolated solution $10^{-2} \mathrm{~mol} \mathrm{~L}^{-1}$ ), unfortunately a tremendously decrease of the column permeability is quickly observed, entailing the collapse of the resin bed; consequently we decided to replace the microporous resin by a macroporous cation exchanger bearing sulfonate groups (Bio-Rad AGMP-50). The macropores having a large diameter (exclusion for the molecular weights $>10^{5}$ daltons) make easier the mobile phase access even after the ferric hydroxide precipitation. In addition, the ferric hydroxide finely divided is covering the pore walls giving thus a high ratio area/volume which is quite decisive for the arsenic retention whereas the mobile phase flow rate is only slightly altered.

\section{Arsenite and arsenate retentions with the macroporous cation exchange resin (BioRad AGMP-50)}

The breakthrough curves of arsenite and arsenate solutions $\left(10^{-2} \mathrm{~mol} \mathrm{~L}^{-1}\right)$ are shown on the figure 3 . The $\mathrm{pH}$ values have been adjusted at 10.7 and 5.4 for $\mathrm{As}^{\mathrm{III}}$ and $\mathrm{As}^{\mathrm{V}}$ respectively. These values are close to the maximum of the distribution curves for $\mathrm{H}_{2} \mathrm{AsO}_{3}^{-}$and $\mathrm{H}_{2} \mathrm{AsO}_{4}^{-}$respectively.

The following remarks can be given:

- The $\mathrm{As}^{\mathrm{III}}$ and $\mathrm{As}^{\mathrm{V}}$ available capacities are quite similar (11.2 and $10.9 \mathrm{mg}$ As per $\mathrm{mL}$ of resin bed respectively). 


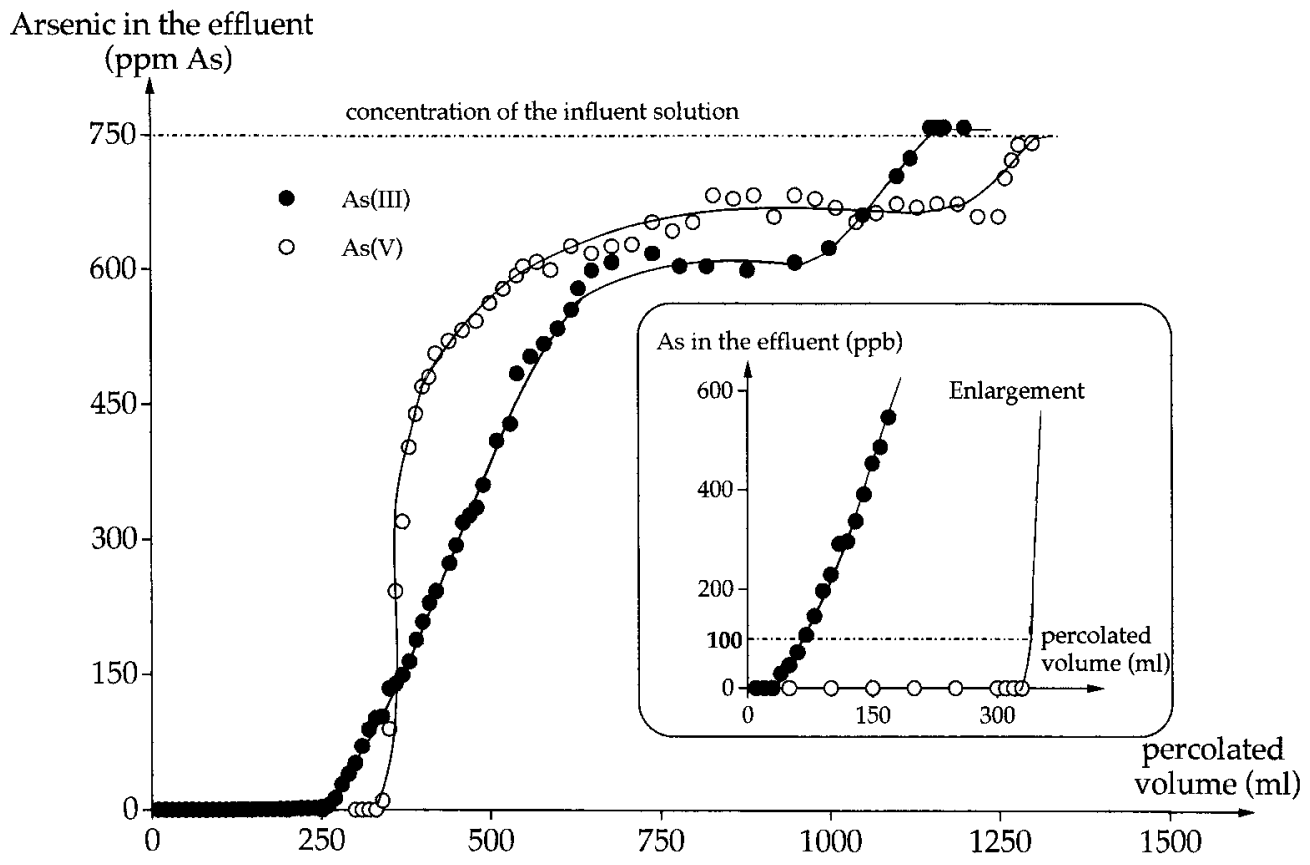

Fig. 3. Arsenite and arsenate breakthough curves. Column: 1 i.d. $\times 47 \mathrm{~cm}$ (resin bed volume: $35 \mathrm{~mL}$ ). Resin: AGMP-50 macroporous cation exchange resin used in its $\mathrm{Fe}^{\mathrm{III}}$ hydrolysed form. Influent: $10^{-2} \mathrm{~mol} \mathrm{~L}^{-1} \mathrm{As}(\mathrm{III}$ and $\mathrm{V}) ; \mathrm{pH} 10.7$ for $\mathrm{As}^{\mathrm{III}}$ and 5.4 for As ; flow rate: $1 \mathrm{~mL} \mathrm{~min}^{-1}$.
These values are the same order of magnitude that the best published results (Tab. II).

- Arsenic retention performed successfully with both sulfonate groups resin (AGMP-50) and chelating groups resin (Chelex 100) shows that only $\mathrm{Fe}^{\mathrm{III}}$ hydrolyzed $\left(\mathrm{Fe}(\mathrm{OH})_{3}\right)$ plays a role in the arsenic fixation.

- The effluent volumes having an arsenic content lower than $100 \mu \mathrm{g} \mathrm{L}^{-1}$ (M.C.L.) are equal to 70 and $330 \mathrm{~mL}$ for $\mathrm{As}^{\mathrm{III}}$ and $\mathrm{As}^{\mathrm{V}}$ respectively. The breakthrough volumes correspond to 10 and $64 \%$ of the arsenic available capacity of the ion exchanger respectively.
- The low volume observed in the case of $A s^{I I I}$ is related to the spreading of the breakthrough curve. This phenomenon can be explained by a low kinetic of arsenite ion fixation in the resin.

\section{Influence of the chloride ion concentration}

The breakthrough curve of arsenite and arsenate solutions $\left(10^{-2} \mathrm{~mol} \mathrm{~L}^{-1}\right.$ each, $\mathrm{pH} 10.6$ for $\mathrm{As}^{\mathrm{III}}$ and 5.5 for $\left.\mathrm{As}^{\mathrm{V}}\right)$ in presence of chloride $1 \mathrm{~mol} \mathrm{~L}^{-1}$ are shown in figure 4 . The $\mathrm{As}^{\mathrm{III}}$ and $\mathrm{As}{ }^{\mathrm{V}}$ available capacities are not significantly affected (9.7 versus 11.2 and 12.4 versus $10.9 \mathrm{mg}$ As

Arsenic in the effluent

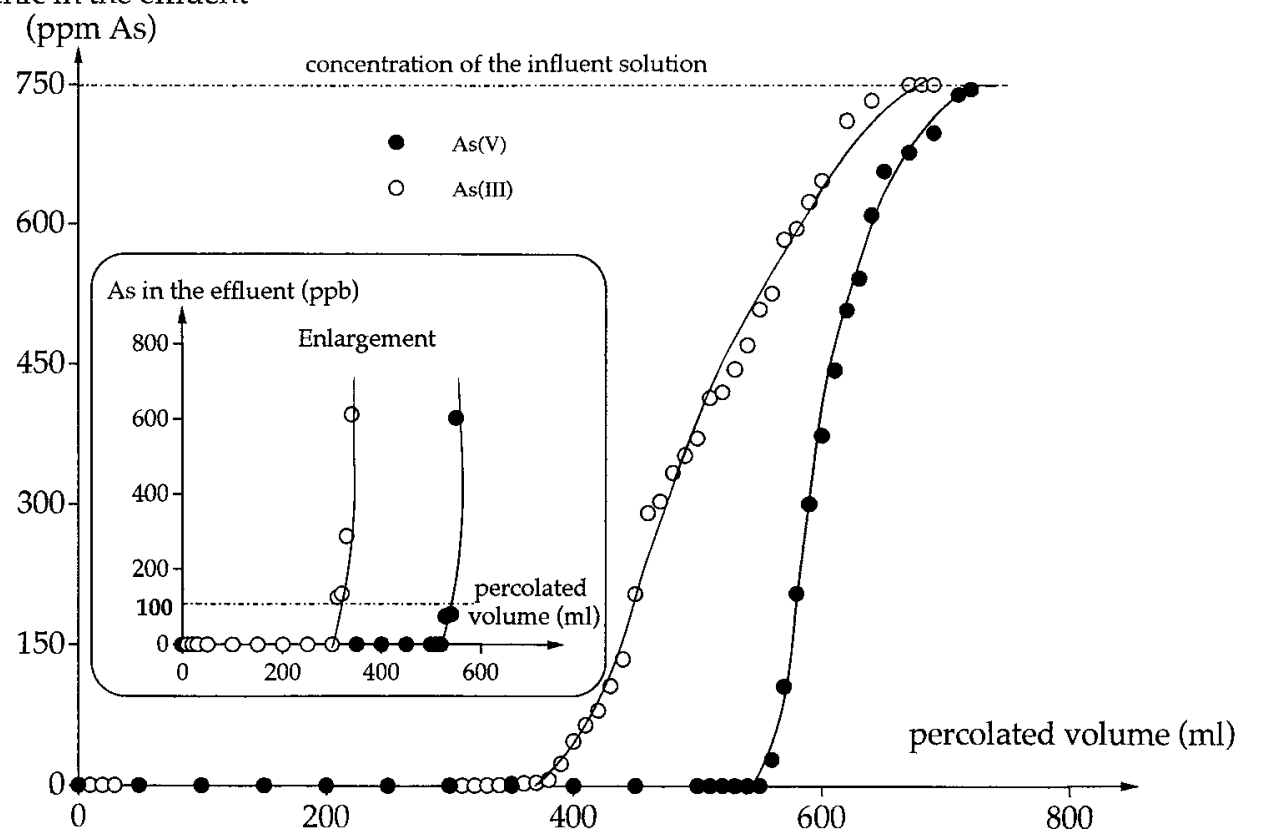

Fig. 4. Arsenite and arsenate breakthrough curves. Influence of chloride ion concentration. Column: 1 i.d. $\times 47 \mathrm{~cm}$ (resin bed volume: $35.9 \mathrm{~mL}$ ). Resin: AGMP-50 macroporous cation exchange resin used in its $\mathrm{Fe}^{\mathrm{III}}$ hydrolysed form. Influent: $10^{-2}$ mol L ${ }^{-1} \mathrm{As}$ (III and V), $1 \mathrm{~mol} \mathrm{~L}^{-1}$ $\mathrm{Cl}^{-} ; \mathrm{pH} 10.6$ for $\mathrm{As}^{\mathrm{III}}$ and 5.5 for

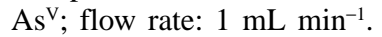




\section{Original articles}

per $\mathrm{mL}$ of resin bed respectively) by the chloride ion concentration one hundred times more concentrated than arsenic.

As we can see it, the profile spreading is much more lower than those observed without chloride ions. An explanation can be found in a salting-out effect, by analogy with liquid-liquid extraction where the extraction of a compound is improved by the addition of an electrolyte to the aqueous phase. The resulting breakthrough volumes are increasing (320 and $540 \mathrm{~mL}$ containing lower than $100 \mu \mathrm{g} \mathrm{L} \mathrm{L}^{-1}$ are obtained for $\mathrm{As}^{\mathrm{III}}$ and $\mathrm{As}^{\mathrm{V}}$ respectively). The breakthrough volumes correspond to 64 and $90 \%$ of the arsenic available capacity of the ion exchanger respectively.

\section{Application to the arsenic removal from the effluent obtained after the first detoxication step.}

The residual concentration of arsenite or arsenate ions obtained after a static treatment with iron(III) of hydrolysis solutions is about $10 \mathrm{ppm}$ As. Consequently, we had to study the final detoxication step with arsenite and arsenate trace solutions containing high chloride anion contents $\left(\approx 1 \mathrm{~mol} \mathrm{~L}^{-1}\right)$.

The figure 5 shows the breakthrough curve of supernatants obtained after a static treatment with iron(III) of arsenite solutions (initial concentrations in chloride and arsenite ions equal to 3 and $0.1 \mathrm{~mol} \mathrm{~L}^{-1}$ respectively) on a 1 i.d. $\times 13 \mathrm{~cm}$ column packed with the macroporous cation exchanger resin used in its $\mathrm{Fe}^{\mathrm{III}}$ hydrolyzed form. The static treatment was carried out at $\mathrm{pH} \mathrm{9,} \mathrm{maintained} \mathrm{constant,}(\mathrm{pH}$ corresponding to the optimal fixation of $\mathrm{As}^{\mathrm{III}}$ on ferric hydroxide [1]) and with a molar ratio $\mathrm{Fe}^{\mathrm{III}} / \mathrm{As}^{\mathrm{III}}$ equal to 1.5 . This ratio allows us to obtain both an arsenic elimination rate greater than 99\% [1] (residual arsenic content equal to $(10.8 \pm 0.2) \mathrm{ppm}$ As) and a high confining of arsenic in the ferric hydroxide precipitate [1].

The same experiment was realized with a standard arsenate solution at $\mathrm{pH} 5.5\left(10 \mathrm{ppm}\right.$ As and $\left.1 \mathrm{~mol} \mathrm{~L}^{-1} \mathrm{Cl}^{-}\right)$. The corresponding breakthrough curve is shown in figure 6 .
We can see the effluent volumes having an arsenic content lower than $100 \mu \mathrm{g} \mathrm{L} \mathrm{L}^{-1}$ are equal to 2.8 and $5.4 \mathrm{~L}$ for arsenite and arsenate respectively. These values correspond to 44 and $85 \%$ of the arsenic available capacity of the ion exchanger respectively. We must keep in mind that these values are obtained with a resin bed volume equal to $10 \mathrm{~mL}$ $(13 \times 1 \mathrm{~cm}$ i.d. $)$; a simple extrapolation shows that the detoxication of an effluent volume equal to $1 \mathrm{~m}^{3}$ from $10 \mathrm{ppm}$ to $100 \mathrm{ppb}$ (the arsenic's M.C.L.) would require a resin bed volume equal to 3.6 and $1.9 \mathrm{~L}$ for $\mathrm{As}^{\mathrm{III}}$ and $\mathrm{As}^{\mathrm{V}}$ respectively. For instance, these values correspond to a chromatographic column having the following dimensions: $72 \times 8 \mathrm{~cm}$ i.d. for $\mathrm{As}^{\mathrm{III}}$ and $68 \times 6 \mathrm{~cm}$ i.d. for $\mathrm{As}^{\mathrm{V}}$.

\section{Conclusion}

The final detoxication of solutions resulting from the arsenite or arsenate ions trapping during the ferric hydroxide precipitation [1] cannot be performed with a classical anion exchanger such as $\left(\mathrm{R}-\mathrm{N}^{+}\left(\mathrm{CH}_{3}\right)_{3}\right)$. This is due to the fact that its selectivity towards arsenic even with negative charges is too low to counterbalance the differences in concentration arsenic oxoanions/chloride anions.

In return, the ferric hydroxide precipitated within the pores of a macroporous resin bearing sulfonate groups allows to obtain the final detoxication of supernatants obtained after a static treatment of the hydrolysis solution of Lewisites [1]. Whatever the arsenic form, the arsenic available capacity of the stationary phase is not affected or even may be increased by the high contents in chloride ions ( 1 to $\left.3 \mathrm{~mol} \mathrm{~L}{ }^{-1}\right)$. These results demonstrate the mechanism involved in the $\mathrm{As}^{\mathrm{III}}$ and $\mathrm{As}^{\mathrm{V}}$ retention is quite different of a pure ion exchange mechanism. In addition, the fact that the $\mathrm{As}^{\mathrm{III}}$ and $\mathrm{As}{ }^{\mathrm{V}}$ retention does not depend on the nature of the resin functional group (aminodiacetate for Chelex 100 [6] and sulfonate for AGMP-50) confirms that this mechanism involves only ferric hydroxide scattered within the pores of
Fig. 5. Arsenite traces breakthrough curve. Column: 1 i.d. $\times$ $13 \mathrm{~cm}$ (resin bed volume: $10 \mathrm{~mL}$ ). Resin: AGMP-50 macroporous cation exchange resin used in its $\mathrm{Fe}^{\mathrm{III}}$ hydrolysed form. Influent: $\mathrm{As}^{\mathrm{III}} 11 \mathrm{ppm}$ As resulting from the static treatment of a solution $0.1 \mathrm{~mol} \mathrm{~L} \mathrm{~L}^{-1} \mathrm{As}^{\mathrm{III}}, \mathrm{Cl}^{-}$ $3 \mathrm{~mol} \mathrm{~L}^{-1}$ with iron(III) $(\mathrm{pH}$ 9, molar ratio $\left.\mathrm{Fe}^{\mathrm{III}} / \mathrm{As}^{\mathrm{III}} 1.5\right)$; flow rate $1 \mathrm{~mL} \mathrm{~min}^{-1}$.
$\mathrm{As}$ (III) in the effluent (ppm As)

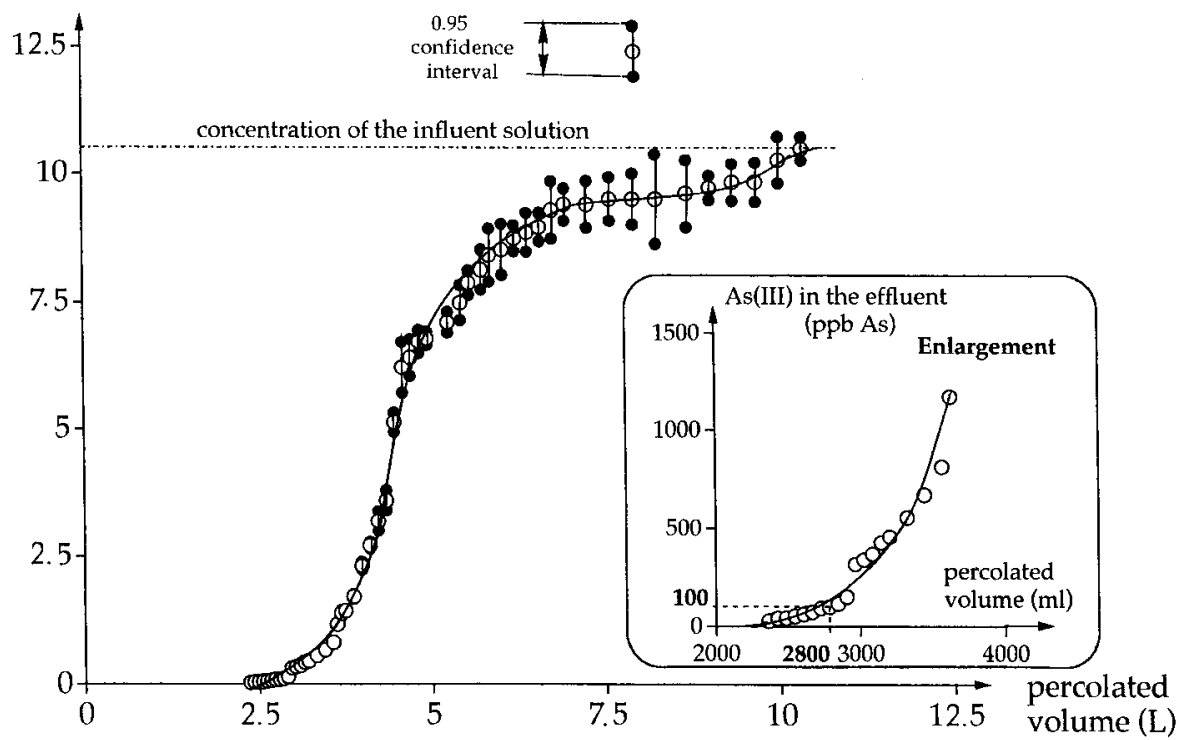


$\mathrm{As}(\mathrm{V})$ in the effluent

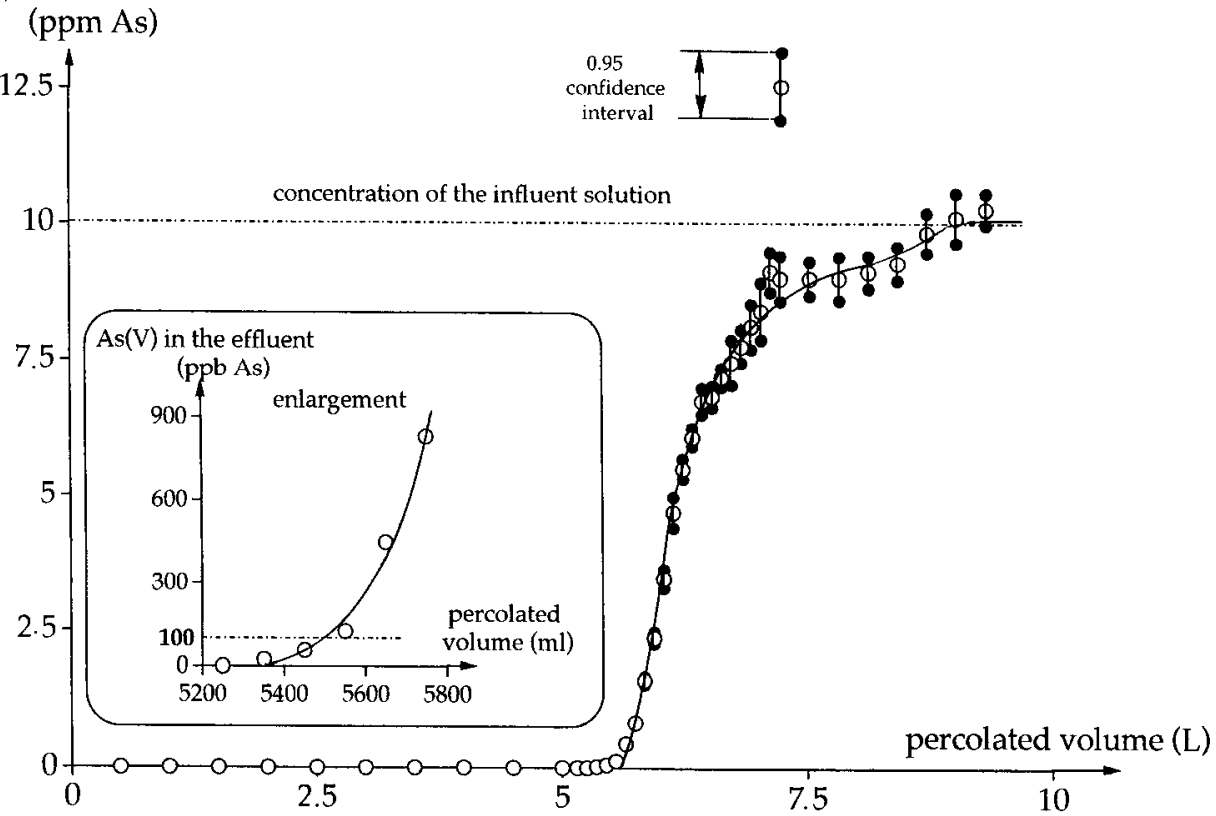

Fig. 6. Arsenate traces breakthrough curve. Column: 1 i.d. $\times 13 \mathrm{~cm}$ (resin bed volume: $10 \mathrm{~mL}$ ). Resin: AGMP50 macroporous cation exchange resin used in its $\mathrm{Fe}^{\mathrm{III}}$ hydrolysed form. Influent: standard $\mathrm{As}^{\mathrm{v}} 10 \mathrm{ppm}$ As, $\mathrm{Cl}^{-} 1 \mathrm{~mol} \mathrm{~L}^{-1}$; $\mathrm{pH}$ 5.5; flow rate $1 \mathrm{~mL} \mathrm{~min}^{-1}$.

the resin. For the purpose of an industrial use the macroporous resin will be the right choice for two reasons:

- low cost,

- high flow rate due to the high column permeability.

The study of its regeneration step is in progress but already this advocated method seems well suited for an industrial implementation. The main reason lies in the fact that a resin bed volume equal to $3.6 \mathrm{~L}$ (for instance a $72 \times 8 \mathrm{~cm}$ i.d. column) allows the complete detoxication of $1 \mathrm{~m}^{3}$ of Lewisites hydrolysis solutions.

\section{References}

1. Guénégou, T.; Tambuté, A.; Jardy, A.; Caude, M. Analusis 1997, 25, 279-286.

2. Minesterial order of February, $18^{\text {th }} 1994$, Storage of special industrial wastes, Journal Officiel de la République Française, 1994; pp 6117-6124.

3. Kartinen, E. O. Jr.; Martin, C. J. Desalination 1995, 103(1-2), 79-88.
4. Kuhlmeier, P. D.; Sherwood, S. P. Water Environ. Res. 1996 68(5), 946-951.

5. Sato, H.; Shiegeta, S.; Uchida, H. Japanese patent $n^{\circ} 55.8843$, 1980.

6 Chanda M., O’Driscoll K.F., Rempel G.L. Reactive Polym. 1988, 8, 85-95.

7. Chanda, M.; O’Driscoll, K. F.; Rempel, G. L. Reactive Polym. 1988, 7, 251-261.

8. Shiegetomi, Y.; Hori, Y.; Kojima, T. Bull. Chem. Soc. Jpn. 1980, 53, 1475-1476.

9. Yoshida, I.; Kobayashi, H.; Ueno, K. Anal. Lett. 1976, 9(12), $1125-1133$.

10. Hlavay, J.; Foldi-Polyak, K.; Inczedy, J. Stud. Environ. Sci. 1984, 23, 373-380.

11. Isaacson, A. E.; Corwin, R. R.; Jeffers, T. H. In: Proceedings of the annual hydrometallurgy meeting on the impurity control disposal hydrometallurgic processes, Harris, B.; Krause, E. Eds., Montréal, Canada.

12. Maeda, S.; Ohki, A.; Tsurusaki, Y.; Takeshita, T. Sep. Sci. Technol. 1990, 25(5), 547-555.

13. De Vitre, R.; Belzile, N.; Tessier, A. Limnol. Oceanogr. 1991, 36(7), 1480-1485.

14. Ringbom, A. Les Complexes en Chimie Analytique, Dunod, Paris, 1967. 